\title{
A teoria teológica da religião de David Tracy
}

\author{
David Tracy's theological theory of religion
}

\author{
Jefferson Zeferino* \\ Rudolf von Sinner**
}

\begin{abstract}
Resumo
Ao se ocupar da pesquisa acerca da teoria teológica da religião formulada a partir do pensamento do teólogo jesuíta estadunidense David Tracy, o presente texto objetiva recolher impulsos para o estudo teológico da religião. Para tanto, examinam-se as obras Blessed Rage for Order: the new pluralism in Theology (1975), A imaginação analógica: a teologia cristã e a cultura do pluralismo (texto original de 1981) e Plurality and ambiguity: hermeneutics, religion, hope (primeira edição de 1987) no que tange à definição de religião. Como resultado das contribuições tracyanas ao estudo teológico da religião destacam-se: 1. Uma abordagem não totalizante da religião; 2. A percepção das pluralidades e ambiguidades que envolvem a investigação da religião e das interpretações da religião; 3. A imaginação analógica entre os estudos da religião e os estudos da arte. 4. A conversação com os clássicos religiosos; 5. Uma dimensão profética das religiões e dos estudos da religião.
\end{abstract}

Palavras-chave: David Tracy; teoria da religião; estudos da religião.

\begin{abstract}
Based on the research of the Jesuit American Theologian David Tracy's theological theory of religion this text aims to think its impulses to the theological study of religion. So, the paper analyses the works Blessed Rage for Order: the new pluralism in Theology (1975), A imaginação analógica: a teologia cristã e a cultura do pluralismo (The Analogical Imagination: Christian Theology and the Culture of Pluralism 1981, original edition) and Plurality and ambiguity: hermeneutics, religion, hope (1987, first edition) concerning the definition of religion. As tracyan contributions the the theological study of religion we highlight: 1 . The need of a non-totalizing approach to religion; 2 . The comprehension of the pluralities and ambiguities concerning religions and the investigation of religions; 3 . The analogical imagination between the religious studies and the studies of art; 4 . The conversation with the religious classics; 5. The prophetic dimension of religions and of the religious studies.
\end{abstract}

Keywords: David Tracy; theory of religion; religious studies.

\footnotetext{
Artigo submetido em 03 de julho de 2019 e aprovado em 29 de agosto de 2019.

* Doutor em Teologia pela PUCPR. Professor colaborador da PUCPR. País de origem: Brasil. E-mail: jefferson.zeferino@hotmail.com

** Doutor em Teologia pela Universidade de Basileia (Suíça). Professor da PUCPR. País de origem: Suíça. E-mail: rudolf.sinner@pucpr.br
} 


\section{Introdução}

É de Faustino Teixeira (2014, p. 35) a expressão tão óbvia quanto esclarecedora de que “As religiões estão aí!”. Neste horizonte, as religiões e, mais amplamente, o fenômeno religioso, tornam-se objeto de estudo de variadas ciências. Evidentemente, constatar que as religiões estão aí é inegável, mas ainda não resolve o que se pode ou deve compreender por "religião".

Essa problemática é intensificada quando nem mesmo uma religião particular pode ser definida sem restrições. Aquilo que é chamado de hinduísmo, por exemplo, emergiu de uma construção europeia e não propriamente como unidade própria das experiências religiosas identificadas como hindus, embora hoje os próprios indianos utilizem esta designação (BECKE, 1996, p. 11-12). ${ }^{1} \mathrm{O}$ mesmo vale para o conceito "religião" que desenvolve seu sentido universalista como fenômeno único e sistema a parte da sociedade, da política, da economia e da ciência, na modernidade europeia (PICH, 2013; WIRTH, 2013).

Acerca do cristianismo, cada vez mais diverso, seria possível questionar: Qual seria a definição mínima que permite que uma pessoa ou uma comunidade afirme sua pertença à fé cristã? O missiólogo e ecumenista escandinavo Mika Vähäkangas estuda o caso de uma igreja que pode ser considerada bastante peculiar no contexto do Conselho Mundial de Igrejas em virtude de sua interpretação da fé cristã: A igreja Kimbanguista, fundada por Simon Kimbangu, acredita que seu fundador seria a encarnação do Espírito Santo. Diante de situações como essa o autor busca equacionar a questão indicando que apesar das distintas intepretações que possam emergir de diferentes igrejas em distintos contextos, a Bíblia pode ser destacada como referência comum. Mesmo assim, no horizonte do diálogo ecumênico, compreende o missiólogo, corre-se o risco da ausência de uma linguagem compartilhada que permita um diálogo efetivo (VÄHÄKANGAS, 2010, p. 12; 2014, p. 51-67).

\footnotetext{
${ }^{1}$ Ainda conforme Becke, cabe informar que sua origem está na palavra persa "hindu" (grego indos, de onde deriva a designação "Índia" e "indianos"), no singular referente ao rio Indus que cruza o que hoje é o Paquistão, no plural referente à população da região. Os muçulmanos chamaram de "hindus" a população não muçulmana.
} 
No Editorial da Concilium que assina com Mircea Eliade, Tracy segue o mesmo traço da dificuldade de se tratar a religião de modo simplista. Com efeito, expõe o desafio de se pensar a religião num contexto de pluralismo, bem como não aceita definições totalizantes de religião, antes, a percebe como um fenômeno a ser estudado em sua complexidade também pelas abordagens teológicas (TRACY; ELIADE, 1980, p. 3-6).

O presente texto se reconhece enquanto uma aproximação teológica da religião alocada no âmbito dos distintos saberes que se ocupam dos estudos da religião. Com isso, está em pauta também a relevância acadêmica do discurso teológico sobre esse fenômeno. Entre os mais destacados pensadores que levaram a termo o diálogo entre teologia e universidade está o já citado jesuíta estadunidense David Tracy. Entre outros, este autor também está presente no quadro teórico fundamental para se pensar uma teologia pública, movimento teológico que recebeu destacada atenção no contexto brasileiro nas duas últimas décadas (SOARES; PASSOS, 2011; SINNER, 2018; ZEFERINO, 2018). Com isso, diante da tarefa de uma ciência teológica que ao lado de distintos saberes se ocupa com o estudo da religião no contexto acadêmico, inclusive teológico, se mostra pertinente investigar a compreensão tracyana de religião.

Efetivamente, ocupamo-nos de Blessed Rage for Order: the new pluralism in Theology (1975) ${ }^{2}$, A imaginação analógica: a teologia cristã e a cultura do pluralismo (texto original de 1981) e Plurality and ambiguity: hermeneutics, religion, hope 3 (primeira edição de 1987). Com o intuito de analisar as possíveis contribuições da teoria tracyana da religião para o estudo teológico da religião no âmbito acadêmico e público no Brasil estabelece-se a seguinte estrutura: 1. A compreensão de religião a partir da linguagem do limite; 2. A relação entre arte e religião no horizonte do discurso teológico; 3. Os clássicos religiosos; 4. O diálogo com os clássicos religiosos; 5. Contribuições tracyanas ao estudo teológico da religião.

\footnotetext{
${ }^{2}$ Em tradução livre: "A santa raiva pela ordem: o novo pluralismo teológico".

${ }^{3}$ Em tradução livre: "Pluralismo e ambiguidade: hermenêutica, religião, esperança".
} 


\section{0 que é religião ${ }^{4}$}

A pergunta de fundo que Tracy estabelece, reflete sobre a relevância e veracidade da interpretação religiosa das experiências e linguagens humanas comuns. Entretanto, formular um conceito de religião é bastante difícil, ao que percebe ser justamente não desejável que se tente produzir uma teoria totalizante acerca da religião. Em jogo está a compreensão das características que diferenciam a religião da arte e da moral. Por conseguinte, é justamente a linguagem do limite ou daquilo que é limítrofe que vem a mão neste contexto (TRACY, 1975, p. 91-93).

De modo geral, Tracy acredita que a religião tem a ver com questões existenciais da vida humana tal qual o desejo por liberdade, bem como a busca por uma existência autêntica. E aqui são fundamentais as noções de limite-até (limitto) e limite-de (limit-of). O primeiro conceito está ligado às experiências limítrofes da própria existência humana, como a finitude. O segundo tem a ver com aquilo que fundamenta implicitamente tal experiência, diz respeito àquilo que limita, que é o referente, o fundamento, elemento que o autor identifica com Deus. Em resumo, a linguagem do limite emerge como tentativa de encontro das comonalidades religiosas da experiência e da linguagem humana sem a presunção de uma conceituação estática da religião. Investiga-se, assim, a dimensão religiosa da existência humana que, por sua vez, tem a ver com as situações limítrofes da vida (limit-to) e com a reflexão acerca daquilo que sustenta tais experiências (limitof) (TRACY, 1975, p. 93; 2006, p. 215-217).

É importante notar que Tracy não elabora uma análise de instituições religiosas, mas fala da religião como aquilo que se refere ao fenômeno religioso e que, por sua vez, pode se desdobrar em religiões instituídas e construtos teológicos como distintas formas de expressão religiosa. Com isso, é possível perceber que o autor parte da experiência humana, identificando nela uma dimensão religiosa que não é, necessariamente, institucionalizada - que pode expressar-se em

\footnotetext{
${ }^{4}$ Para esta parte nos baseamos, principalmente, no capítulo quinto de Blessed Rage for Order intitulado The Religious Dimension of Common Human Experience and Language, bem como nas partes de $A$ imaginação analógica em que o autor também se dedica às noções de limite no âmbito da religião.
} 
distintas religiões específicas. É neste contexto que o autor compreende que são justamente as religiões particulares que servem de base para se pensar o significado de religião. Para Tracy, a dimensão religiosa da vida está relacionada com as situações e questões limítrofes da existência humana. Com efeito, em sua própria análise de uma tradição religiosa particular, o cristianismo, não se demora em fazer a relação entre aquilo que denomina de limite-de com o Deus de amor cristão (TRACY, 1975, p. 93-94; 2006, p. 208-220).

Ao falar da experiência humana, o autor se move em bases antropológicas, compreendendo, a partir de Bernard Lonergan, que o ser humano é um ser que transcende a si mesmo na busca de sentidos exteriores a si. Isto ocorre também quando se pergunta pelo valor das coisas, pela dimensão ética da existência. A autotranscedência humana, portanto, não é meramente cognitiva, mas também ética. Com efeito, quando se postula um fim último organizador do pensamento científico, se está no campo dos questionamentos do limite-até e limite-de uma certa experiência e, deste modo, se necessita de uma forma de mediação daquilo que se compreende como último. Há, portanto, uma certa dimensão religiosa da existência que pode ser percebida para além do âmbito explicitamente religioso das religiões concretamente constituídas. Para Tracy, à medida em que situações limítrofes existem, já se está no âmbito do religioso (TRACY, 1975, p. 96-99). Decorre disso, contudo, a necessária ressalva contra o reducionismo do religioso ao ético. Neste contexto, Tracy indica que talvez um dos principais problemas do protestantismo liberal e do catolicismo modernista teria sido a indistinção entre religião e moral. Isto é, o reducionismo de que a religião seria traduzida apenas em via ética (TRACY, 1975, p. 100-101).

As situações limítrofes são multiformes, podendo ser compreendidas tanto como positivas quanto negativas. Elas têm a ver tanto com experiências de amor e alegria, quanto com experiências de doença e sofrimento. Em todo caso, contudo, aquele que passa por tal vivência é levado a uma nova compreensão do mundo e da vida. São, portanto, experiências de revelação de e a partir de uma dimensão limítrofe da existência. Ao que tange a experiência humana comum, as situações e 
questões limítrofes apontam para uma dimensão da vida que pode ser compreendida como religiosa, à medida em que tais experiências limítrofes estão acompanhadas de desvelamentos de sentido para a própria vida humana. Ademais, é comum que se busque expressar estas experiências por meio de metáforas que, por sua vez, são tentativas de tradução simbólica de algo talvez indizível (TRACY, 1975, p. 105-109).

Desse modo, o religioso se movimenta entre a experiência e a linguagem. Com base nas discussões da filosofia analítica, Tracy explica que quando se utiliza a palavra religião se está apontando para a representação de algo que conjuga questões e respostas limítrofes oriundas das vivências humanas. Definição que serve de exemplo da tese tracyana de que esta gramática do limite é um modo, não exaustivo nem totalizante, de categorizar a discussão sobre a religião (TRACY, 1975, p. 104).

É justamente neste âmbito de tradução da experiência religiosa por meio da linguagem que tomam espaço as formas particulares destas expressões. A experiência particular de uma situação limítrofe pode revelar algo (um desvelamento de sentido). É este recorte situacional que “[...] determinará parcialmente que imagens, símbolos, mitos e molduras conceituais serão empregados na teologia sistemática para explicar a realidade do 'limite de"” (TRACY, 2006, p. 225).

As tradições teológicas das religiões, portanto, são tentativas de expressão acerca de um limite-de por meio da interpretação do limite-até. Entrementes, também a interpretação do religioso não pode olvidar ambiguidades. “Experimentamos o suficiente dos terrores deste século ensopado de sangue para não ingressar no diálogo dos clássicos religiosos sem uma experiência que constitui, ela própria, uma experiência inevitavelmente dialética de esperança e medo" (TRACY, 2006, p. 228-229).

Isto posto, cabe atentar a reflexão tracyana acerca dos caminhos possíveis de uma interpretação da religião: 
Sabemos que os clássicos religiosos podem comprovar-se como ilusões e projeções de nossas próprias necessidades infantis ou condições sociais ou de nossa vontade insaciável de poder. [...] Porém, não podemos honestamente descartar a possibilidade de que a religião pode mostrar-se genuinamente reveladora de uma realidade que não pode ser negada. Por isso devemos aderir ao diálogo das religiões sem reservas. Devemos escutar tanto com respeito como com liberdade crítica, tentando expressar aquilo que nós experimentamos e compreendemos - por parcial, por precário que seja - e então seguir em frente. Nós devemos arriscar uma teologia sistemática. (TRACY, 2006, p. 229).

Em suma, Tracy compreende existir na existência humana uma dimensão religiosa que pode ser acessada, sobretudo, por meio das situações e questões limítrofes - aquelas ligadas, por exemplo, a eventos de intenso êxtase ou de intenso sofrimento. Estas situações limítrofes possuem um potencial revelador, que desvela sentidos novos acerca da vida ou ainda ilumina sentidos outrora negligenciados. Da experiência decorre sua tradução em forma de linguagem e, neste horizonte, é possível pensar nas particularidades das experiências de cada religião. Com efeito, é possível que se encontrem expressões clássicas acerca desta dimensão religiosa da existência humana - fala-se agora dos clássicos religiosos.

\section{Os clássicos religiosos}

Os clássicos religiosos são aqueles textos, eventos, símbolos, imagens, rituais que expressam uma determinada experiência religiosa e que sempre comunicam algo, possuem um excesso de sentido, não são exauridos por uma interpretação única - resistem à dominação. Estes clássicos religiosos são sempre de novo reinterpretados no seio de uma determinada expressão religiosa particular e, nesta dinâmica, podem ser a gênese de novos clássicos. As noções de clássicos e clássicos religiosos desenvolvidas de forma extensa por Tracy em A imaginação analógica nos remetem àquilo que pode ser considerado o cerne de sua teoria sobre a religião, a saber, a interpretação das expressões várias das religiões que adquirem um status de clássico por interpelarem de forma sempre nova quem se depara com eles.

Não se trata, contudo, de uma interpretação ingênua, nem ao menos de se tornar absoluta uma forma de interpretação. Pelo contrário, os clássicos religiosos assim o são porque permitem e fomentam discussão e análise crítica. As raízes da 
crítica à religião, portanto, podem ser encontradas no interior das próprias religiões. Nas palavras de Tracy:

[...] essas raízes também estão fundadas nos textos e testemunhos clássicos das tradições judaica e cristã: nas buscas ansiosas e autocríticas dos profetas, no brilhantismo e nas reflexões não-heterônomas sobre o modo de vida da Torá, na busca crítica dos sábios da literatura sapiencial pela manifestação da verdade divina nas situações-limite de nossas vidas - classicamente, no modo profundo do reconhecimento do Livro de Jó, em que cosmos e ethos unem-se no pathos do sofrimento fundado sobre a fé e a esperança. [...] O momento da reflexão crítica nas jornadas religiosas cristã e judaica deve permanecer como um momento clássico na sua consciência religiosa. Nem mesmo a redescoberta da verdade do paradigmático pode eliminar esse momento crítico sem trair o poder paradigmático da própria jornada. (TRACY, 2006, p. 257).

Neste horizonte, é possível perceber um traço de autocrítica no interior de tradições religiosas. Esta dinâmica permite que se vislumbre um caminho de superação de absolutismos e reducionismos, não raro, encontrados na forma de fundamentalismos. Tão clássica quanto o clássico examinado é a predisposição à revisão crítica presente no cerne da tradição judaico-cristã e que permite sua constante atualização.

Além desta auto criticidade evidenciada por Tracy, também cabe destacar seu critério de que a religião pode ser melhor compreendida no âmbito do estudo das religiões: "O único fundamento da expressão religiosa, se a religião de fato é uma manifestação do todo, é esse universal concreto reconhecido como a alegação de ser um evento da verdade expresso em uma religião concreta particular”. O estudo de uma religião específica, portanto, permite um acesso àquela particularidade de tal modo que, investigada à profundidade, faz emergir aquilo que há de comum e de distinto em relação às outras religiões particulares (TRACY, 2006, p. 259).

De modo programático, a relação entre experiência religiosa e reflexão crítica resulta na necessidade de uma hermenêutica de resgate operada por meio da analogia (semelhanças-na-diferença) entre clássicos religiosos e outros clássicos. "A principal similaridade é estrutural: qualquer clássico produzirá seu significado por meio de estratégias correspondentes de intensificação da 
particularidade e intensificação do distanciamento na expressão" (TRACY, 2006, p. 262). Há, portanto, um duplo movimento: interioridade e publicidade. A intensificação da particularidade pode ser identificada com a manifestação, enquanto a intensificação do distanciamento em forma de comunicação partilhável é relacionada com a proclamação (TRACY, 2006, p. 267).

No âmbito da história das religiões, esta dinâmica pode ser exemplificada “[...] por meio do contraste entre dois tipos ideais: as religiões com ênfase místicosacerdotal-metafísico-estética e as religiões com ênfase profético-ético-histórica”. Contudo, estes elementos não podem ser totalmente separados, há, inclusive, ainda hoje, em grandes religiões como o cristianismo, o islamismo e o judaísmo o debate acerca de qual seria a vertente mais destacada. Com efeito, “[...] um estudo de qualquer religião ocidental real mostra que uma compreensão não-dialética das religiões ocidentais se evidencia como míope” (TRACY, 2006, p. 267-270). Em resumo, qualquer estudo das religiões deve evitar reducionismos a todo custo, sendo que a percepção das características das religiões particulares é que permite a criação de um quadro mais amplo daquilo que se pode compreender por religião.

Em sua análise particular, Tracy volta sua atenção ao cristianismo e, sobretudo, destacando o clássico religioso cristão por excelência - dentre as imagens, textos, símbolos, rituais, pessoas, eventos - a saber, a pessoa de Jesus Cristo:

Daí que o cristão cristocêntrico reconhecerá que o evento paradigmático de Cristo desvenda o poder religioso tanto da manifestação como da proclamação. [...] como palavra verdadeira e manifestação decisiva. Daí que o éthos cristão está enraizado na dialética de uma manifestação envolvente, "sempre já", que constantemente é transformada por uma proclamação desfamiliarizadora, com frequência abaladora, "ainda não". E ambas, a manifestação e a proclamação cristãs, estão, em última análise, enraizadas naquele Deus, cuja alteridade radical em liberdade se apresenta a nós como a imanência radical de um amor que a tudo perpassa, desfamiliarizador, abalador, no cosmo, na história, no eu. (TRACY, 2006, p. 294-295). 
Por meio do desenvolvimento teológico de Tracy é possível perceber um duplo movimento: 1. "A teologia fundamental justifica as alegações de verdade da dimensão religiosa da existência com razões públicas ordinárias"; 2. "A teologia sistemática como interpretação justifica as alegações de verdade da religião concreta com aqueles tipos de razões autenticamente públicas, apropriadas ao tipo de publicidade reveladora expressa em todos os clássicos” (TRACY, 2006, p. 259). Assim, o que caracteriza a movimentação da teologia fundamental para a sistemática “[...] é logicamente um movimento das características abstratas, gerais, universais, necessárias, da 'dimensão religiosa', presentes em toda a realidade para a realidade particular, concreta, de uma 'religião explícita”' (TRACY, 2006, p. 220).

Com efeito, a teologia sistemática tem a ver com este despertar para uma dimensão normativa oriunda do contato com os clássicos religiosos. Decorre disso, portanto, [...] a disposição de arriscar uma interpretação da tradição religiosa clássica, a disposição de tornar-se um teólogo sistemático como distinto de um teólogo fundamental, vem a ser uma aposta muito mais responsável”. É neste horizonte que Tracy elabora a seguinte questão: "Pois quem é o teólogo sistemático senão o intérprete dos clássicos religiosos de certa tradição clássica, um intérprete finito, histórico, que corre riscos?” (TRACY, 2006, p. 221).

Em Tracy, portanto, a teologia fundamental estaria mais próxima de um exercício filosófico sobre a religião e, justamente por isso, mais amplo, concentrado na busca das comonalidades religiosas não confessionais - não implicadas ou envolvidas normativamente numa religião particular. A teologia sistemática, por sua vez, seria a fala comprometida com a análise de uma religião particular e envolvida com a razoabilidade das alegações de verdade desta tradição específica. Sua teologia sistemática, portanto, seria aquela abordagem científica que, assim como nos estudos da arte, acontece impactada por aquilo que estuda. Ademais, Tracy elabora aqui a centralidade da reflexão acerca do belo como algo análogo entre religião e arte. 


\section{Arte e religião: uma imaginação analógica}

O âmbito de uma religião particular é espaço privilegiado de investigação do fenômeno religioso. Os estudos da religião, por sua vez, possuem suas particularidades tal qual outras ciências. Por analogia, Tracy aproxima os estudos da religião com os estudos da arte. Com efeito, ao explicar as atribuições das disciplinas teológicas afirma que é justamente a teologia sistemática que se ocupa com o belo:

$\mathrm{Na}$ linguagem alternativa da reflexão transcendental, a teologia fundamental tem a ver principalmente com o "verdadeiro" no sentido da metafísica, a teologia sistemática com o belo (e [...] o belo como o verdadeiro) no sentido da poética e retórica, a teologia prática com o bem (e o bem como verdadeiro transformador) no sentido da ética e política. [...] Por essa razão, o enfoque principal será colocado na relação "artereligião" nas análises dos clássicos e, com distinção, dos clássicos religiosos (TRACY, 2006, p. 89, nota 31).

A interpretação dos clássicos religiosos interpela existencialmente: “[...] nada concentra de tal maneira a atenção do intérprete prospectivo dos clássicos religiosos quanto à sensação poderosa de alguma experiência situacional focada em alguma questão fundamental para a existência [...]”, a saber, "[...] morte, confiança, ansiedade, milagre, lealdade a uma causa maior do eu mesmo, contingência radical, ausência de sentido, admiração, alegria, amor”. Existe, portanto, uma noção de excesso de sentido do clássico religioso. A dimensão sui generis da religião, portanto, tem a ver com sua não dominação definitiva, com a capacidade que possui de trazer à luz questionamentos existenciais, não raro conectados com situações limítrofes. Daí que toda tentativa de aproximação da religião é sempre apenas relativamente adequada (TRACY, 2006, p. 231-232).

Neste contexto, é válido reproduzir o sintético arrazoado que Tracy elabora acerca de importantes estudiosos da religião:

A maioria desses pensadores fornece reflexões explícitas e com frequência mais do que ocasional (especialmente Schleiermacher, Eliade, Otto, van der Leeuw e Tillich) sobre as similaridades entre a experiência com a obra de arte e a experiência com a religião. (James, que ordinariamente relaciona a religião com a moralidade, é a exceção nesse ponto.) Essas 
similaridades podem dar suporte à minha sugestão de que esses pensadores, não obstante toda a sua diversidade, apresentam afinidades de família suficientes para serem considerados candidatos à inclusão no que pode ser chamado de moderna tradição do resgate da natureza sui generis da religião. A meu ver, ademais, o caráter hermenêutico do seu empreendimento, sua insistência obtida a posteriori no caráter sui generis da religião, sua insistência na necessidade de interpretar as expressões religiosas clássicas e sua sensibilidade para as analogias clássicas - com frequência pouco valorizadas por estudiosos da religião e teólogos - entre a experiência com a obra de arte e com os clássicos religiosos dão suporte à minha convicção de que qualquer pessoa que aceita as análises anteriores desta obra (sobre a interpretação dos clássicos) não estranhará que, nesta seção da obra, eu me volte principalmente a esses modernos mestres do resgate dos clássicos religiosos tanto na qualidade de religiosos como na qualidade de clássicos (TRACY, 2006, p. 232, nota 66).

Ora, aquilo que é investigado também investiga a quem o investiga. Não há escapatória, no encontro com os clássicos religiosos, assim como no encontro com os clássicos da arte, se é interpelado e às vezes isto acontece de tal modo que desvendamentos de sentido acerca da existência vem à tona. "A pessoa genuinamente religiosa (os 'místicos' e 'santos' de James), pelo visto, experimentam essa realidade do mistério como uma realidade do sagrado, que traz em si uma força avassaladora e transformadora da vida" (TRACY, 2006, p. 233234).

Para Tracy, o que une as análises sobre o fenômeno religioso aos estudos da arte, é "[...] a insistência em que a responsabilidade primordial do intérprete da religião é descrever a própria experiência como ela se apresenta à consciência”. Por sua vez, a descrição, que é uma interpretação, busca elaborar uma linguagem relativamente adequada ao evento de desvendamento que foi experimentado (TRACY, 2006, p. 235). O fenômeno religioso, portanto, exige uma dupla hermenêutica, de resgate (de atualização do seu sentido) e de suspeita, até porque, não raro, estes clássicos "[...] são concretizados e, com frequência, institucionalizados em tradições religiosas concretamente ambíguas" (TRACY, 2006, p. 237, nota 71). 
Há, certamente, que se indicar que sãos as particularidades do clássico religioso que permitem sua distinção da moral, da ciência, da arte e da política. Aquilo que é experimentado no horizonte religioso, revela algo de normatividade, um princípio organizador da existência que está conectado com um limite-de. Aqui está a noção de todo que Tracy desenvolve em $A$ imaginação analógica, que em Plurality and ambiguity é denominado Realidade Última (Ultimate Reality) e que em Blessed Rage for Order se refere a noção tillichiana de Preocupação Última (Ultimate Concern). Este todo, na visão do autor, compromete a vida em sua totalidade (TRACY, 2006, p. 240).

Com efeito, a experiência religiosa remete as pessoas para além de si mesmas. Aí a linguagem da revelação aponta para um algo a partir de fora. “Antes, elas se veem compelidas a honrar essa experiência realizada como a erupção de um poder que se tornou automanifestação da parte e por meio do todo no qual, pelo qual e para o qual elas vivem”. Ademais, “[...] a totalidade chegou à sua vida não como realização pessoal, mas como dádiva da parte do todo; acima de tudo, a maneira como alguém deve viver está fundada, em última análise, no que a própria realidade é”. Com isso, a dimensão ética da vida resulta influenciada pela experiência religiosa (TRACY, 2006, p. 241-242).

Novamente, aquilo que se experimenta “[...] não desvenda a certeza de uma clareza e um controle, mas uma realidade de poder ao mesmo tempo tremendum et fascinans" (TRACY, 2006, p. 193; 242-244; cf. OTTO, 2007, p. 44-78). Neste horizonte, talvez a postura mais adequada seja o silêncio. Ou, ao menos, a percepção de que toda abordagem é apenas relativamente adequada.

As revelações ou desvendamentos de sentido e verdade proporcionadas pelos clássicos religiosos não podem ser assumidos como fonte de certeza inequívoca. "Esse mundo não exige uma compreensibilidade tecnicamente controlada, mas liberta o eu para a incompreensibilidade incontrolável da experiência com o mistério radical”. Este caráter incontrolável da religião, por sua 
vez, é algo que depõe contra os fundamentalismos e pretensões de domínio da verdade total de um clássico religioso. "Afortunadamente, sempre se pode contar com os próprios clássicos religiosos para desafiar radicalmente essas distorções” (TRACY, 2006, p. 247-248).

É justamente esta experiência particular (interioridade, manifestação) que demanda uma publicização (comunicação partilhável, proclamação). Entrar em contato com o mundo dos clássicos, portanto, é encontrar desvendamentos de sentido e verdade, não raro, evocados por situações limítrofes. Ademais, "todo clássico religioso expressa um evento da realidade 'limite de', que possui a força plena de um poder que finalmente nos liberta de nós mesmos, convocando-nos para e por meio de um poder que não é o nosso próprio” (TRACY, 2006, p. 248).

A proposta tracyana aqui exposta pode ser sintetizada na imaginação analógica que estabelece entre religião e arte. Portanto, é possível dizer que, por analogia, Tracy aproxima o fenômeno religioso do fenômeno da arte e, nesta direção, semelhantes particularidades que, metodologicamente, são implicadas no estudo da arte também podem ser aplicadas ao estudo da religião. Em resumo, assim como a experiência estética provocada pela obra de arte transcende os próprios métodos do estudo da arte, assim também a experiência religiosa ultrapassa os limites dos estudos da religião. Com efeito, assim como se mostra pertinente o diálogo com os clássicos da arte, é possível afirmar a relevância do diálogo com os clássicos religiosos.

\section{0 diálogo com os clássicos religiosos}

O autor que utiliza a imaginação analógica como pressuposto e método desenvolve no texto de 1981 o diálogo com os clássicos religiosos como grande desafio de uma teologia sistemática. O texto de 1987, Plurality and ambiguity: hermeneutics, religion, hope, por sua vez, inicia com a declaração de que seu tema central é a conversação. Mais, nesta conversação é que as tradições religiosas são 
chamadas a reconhecer suas pluralidades e ambiguidades. Com efeito, seu intento é o de pensar uma possível interpretação da religião, compreendendo a esperança como elemento central do fenômeno religioso, bem como a própria religião como locus suficientemente complexo para testar as tentativas de hermenêutica desta realidade (TRACY, 1994, p. ix-X).

\subsection{A conversação}

De início, Tracy define que a hermenêutica lida com a interação entre o intérprete e aquilo que é interpretado. Em relação a este fenômeno a ser interpretado, evoca-se a importância central dos textos escritos em culturas letradas e dentre estes textos destacam-se aqueles que podem ser considerados como clássicos. Estes, por sua vez, se tornam o momento de prova de distintas teorias de interpretação. Até porque, como anteriormente estabelecido, um clássico assim o é, em virtude de seu excesso de sentido e resistência a qualquer interpretação definitiva (TRACY, 1994, p. 10-12).

Tracy explica que sempre há uma pré-compreensão, que pode estar baseada em uma determinada tradição, em relação a algo que será interpretado, mas que também pode existir, por parte do intérprete, a predisposição de colocar tal précompreensão em risco à medida em que se permite ser questionado pelo clássico. Diante disso, emerge a noção de conversação. É no jogo da conversação que os questionamentos acontecem e que o assunto assume seu protagonismo. Isto é, o assunto tratado pelo texto é pensado e questionado pelo leitor e pelo texto e a prática de ir adiante tanto o quanto um assunto exige é que pode se chamar de diálogo (TRACY, 1994, p. 16; 18).

A conversação pode ser caracterizada por sua busca pela verdade e pelo reconhecimento das diferenças e da alteridade. Na compreensão do outro enquanto realmente outro é que a diferença deve ser entendida como possível. Em jogo estão semelhanças e diferenças e, deste modo, semelhanças-na-diferença (definição 
daquilo que Tracy entende por analogia). Uma imaginação analógica, portanto, é aquela que assume o risco da interpretação das semelhanças-na-diferença entre aquilo que é revelado e escondido e que compreende que é o assunto o protagonista da conversa (TRACY, 1994, p. 20). 5

A hermenêutica tracyana, portanto, permite pensar não só a pluralidade de discursos ou abordagens sobre um tema, mas também percebe a possibilidade de identificar as ambiguidades presentes nos estudos de religião. Deve-se, inclusive, resistir aos discursos reducionistas que vendem coerências homogêneas sem ambiguidades que, não raro, são legitimadoras de poderes instituídos. Para Tracy, as religiões são redutos de resistência que não negam nem suas próprias pluralidades e ambiguidades. Ademais, também resistem à inatividade, isto é, elas agem diante dos problemas de cada tempo (TRACY, 1994, p. 82-84).

Apesar da precariedade de sua fala na tentativa de estudar os clássicos religiosos, teólogos e teólogas, e aqui Tracy indica o exemplo de Mahatma Gandhi e Martin Luther King Jr., sempre de novo possuem um horizonte de esperança ética, nutrida por sua confiança numa Realidade Última (Ultimate Reality), descobrindo novas possibilidades de ação em resistência ao status quo. Entretanto, qualquer fala em favor da religião que não perceba suas ambiguidades e não combate suas violências, fanatismos, obscurantismo e exclusivismos não pode ser considerada no âmbito desta resistência ética à luz da esperança ${ }^{6}$. A teologia, como um modo de estudo da religião, na tarefa de interpretar clássicos, é sempre precária. A mesma pluralidade e ambiguidade presente em outros modos de discurso também faz parte da fala teológica. Assim, teólogos e teólogas devem ser interpretados diante de suas contingências, demandando, quando devido, resgate, crítica e suspeita (TRACY, 1994, p. 84-86).

\footnotetext{
${ }^{5}$ Aqui Tracy trabalha com a famosa distinção de Lutero, elaborada especialmente no seu debate com Erasmo (LUTERO, 1993, p. 99108), sobre a qual Tracy falou de forma mais extensiva em Tracy (2015).

${ }^{6}$ Em certa consonância, é possível citar o teólogo luterano Enio Mueller (2007) que - ao pensar a teologia no diálogo com outros saberes diante do reconhecimento da teologia como curso superior pelo Ministério da Educação (MEC) - afirma, baseado em Lutero, que o aspecto distintivo da teologia é sua leitura da realidade à luz da esperança.
} 
Os questionamentos sobre a religião levam a pensar a relação que a Realidade Última possui com o ser humano, sendo que os clássicos religiosos são, de modo recorrente, as tentativas de se pensar esta relação e, não raro, há a percepção de teólogos e teólogas de que tais respostas são construídas já na relação com tal Realidade Última (revelação). Há também a possibilidade de que outros estudiosos da religião estabeleçam outros tipos de abordagem, mas todos que se dedicam a este estudo devem conversar com os clássicos religiosos (TRACY, 1994, p. 87-89).

Há, portanto, também uma dimensão antropológica que precisa ser considerada. Com efeito, cabe notar as próprias ambiguidades da existência humana em sua finitude e desejo de libertação por algo externo. Diante disso, emerge uma possibilidade de iluminação oriunda das tradições religiosas que - e aqui Tracy se baseia em John Hick quem conceitua o transcendente genericamente como "the Real" 7 - em última análise, remetem a uma conversão de uma centralidade ensimesmada do ser para uma forma de ser centrada na Realidade (Reality-centeredness). Pensa-se numa transformação libertadora do ser. Entretanto, esta comonalidade não pode ser reducionista, isto é, cabe ver que cada religião particular possui suas próprias formas de expressão e compreensão da realidade humana. Neste contexto, portanto, não se torna possível dizer que todas expressões são as mesmas, mas trata-se de apontar para uma perspectiva comum de transformação do ser. O que não impede que as distintas religiões, na medida em que se colocam em relação, se permitam aprender das experiências das outras tradições religiosas, ao mesmo tempo, também há elementos que podem ser refutados nesta interação, contudo, qual procedimento ocorrerá só poderá ser definido uma vez que a conversa estiver em andamento (TRACY, 1994, p. 89-90).

Neste ponto, Tracy compreende que a relação entre religião e sociedade, por meio de critérios ético-políticos, pode ser um ponto de referência para se pensar a conversa entre as religiões. Assim como há uma pluralidade de interpretações também há conflitos entre interpretações e aí está o ponto de que para uma

\footnotetext{
${ }^{7}$ Para obras de Hick disponíveis em português, ver Hick (2005; 2018).
} 
compreensão mais ampla dos assuntos em questão, as próprias opiniões mais rígidas também devem ser ouvidas. Ademais, mesmo a postura pluralista deve caracterizar seus critérios para que possa ser também avaliada criticamente (TRACY, 1994, p. 91-92).

De acordo com o teólogo jesuíta a conversação entre as religiões, mais do que possível, é uma necessidade. Não uma conversa reducionista que tenta eliminar as diferenças dizendo que todas as religiões são iguais, mas uma conversa que leva a sério as diferenças e a possibilidade do encontro de semelhanças. E talvez a forma mais clara de reducionismo seja uma abordagem totalizante, que admite apenas uma forma de compreensão do fenômeno religioso. A imaginação analógica tracyana indica uma vontade de se entrar na conversa com a disposição de se arriscar certas pressuposições à medida em que se considera o outro (este outro também pode ser identificado como o clássico religioso) seriamente em sua alteridade - com suas diferenças, semelhanças e pretensões de verdade - para que se possa, de fato, compreendê-lo. Mesmo assim, esta aproximação do outro - por mais aberta e desejosa de aprender do outro ou do clássico que seja - sempre será apenas relativamente adequada (TRACY, 1994, p. 92-93; 98-100).

\section{2 Ética e hermenêutica}

A teologia latino-americana da libertação aprendeu a valorizar a importância das expressões religiosas mais populares. Diante disso, o próprio Tracy reconhece que sua teologia dos clássicos precisa desenvolver maior sensibilidade à estas práticas religiosas cotidianas (TRACY, 1994, p. 96-97).

Em consonância, teologias judaicas e cristãs têm atentado cada vez mais para a necessária relação entre teologias místicas e políticas e, com isso, a profunda conexão entre espiritualidade e ética. Este movimento tem a ver também com uma criticidade em relação a discussões teológicas elitistas preferindo uma dinâmica mais prática. Isto tem a ver com as teologias do cotidiano, que Tracy identifica nas assim chamadas teologias das ruas (street theologies) que narram a vida das 
pessoas cristãs; no giro místico-político de certas comunidades monásticas; em teologias evangelicais que valorizam as questões de justiça social; nas comunidades eclesiais de base em relação com as teologias de libertação; na proposta de solidariedade entre distintas comunidades cristãs europeias. Estas teologias práticas, ou ainda, estes discursos sobre as religiões vividas ${ }^{8}$, portanto, influenciam os estudos da religião (TRACY, 1994, p. 102).

Da reflexão sobre as teologias práticas, com especial atenção às teologias de libertação, decorre a noção de que os clássicos religiosos assim o são por serem inteligíveis a todas as pessoas. Mais, os clássicos proféticos da tradição judaicocristã indicam uma certa preferência, a saber, que o Deus dos profetas é um Deus sensibilizado com a realidade daqueles e daquelas que mais sofrem. Isto leva a noção de que na tradição cristã, a salvação não pode ser exaurida na noção de libertação política, mas também não pode ser compreendida sem esta dimensão (TRACY, 1994, p. 103-104).

Também aqui a interpretação da religião deve ser crítica, isto é, não é pelo fato de que uma determinada abordagem considera a realidade de opressão que ela está livre de ambiguidades. Há uma responsabilidade de se escutar estas demandas, de ação, arrependimento, reconhecimento de culpa, mas também há a necessidade de se resistir a certas interpretações quando necessário. Isto demonstra que uma conversação autêntica não se esquiva de possíveis conflitos hermenêuticos (TRACY, 1994, p. 106-107).

De acordo com Tracy, com base na tradição cristã, fé, esperança e amor religiosos colocam o humano diante do mistério de si, da história (e natureza) e da Realidade Última (fé); além de libertar das ilusões do pessimismo e do otimismo (esperança) e de uma predisposição egocêntrica de domínio sobre as outras pessoas (amor). Ademais, todo ser humano existe dentro de uma história e de uma narrativa (discurso), e o percurso de humanização do humano acontece na relação

\footnotetext{
${ }^{8}$ Aqui Tracy não utiliza o termo lived religion, mas, certamente, as reflexões neste campo podem auxiliar a construir este quadro de teologias que se ocupam com o cotidiano. Sobre este aspecto, no Brasil, ver especialmente as discussões ensejadas por Júlio Cézar Adam (2017; 2018).
} 
crítica com as distintas tradições de interpretação sobre o humano. De igual modo, as religiões também existem em relação com as histórias e narrativas das distintas religiões. Neste contexto, cabe também a percepção das diferenças, pois compaixão budista e amor cristão não são idênticas. Mas ambas demonstram modos, que podem ser complementares e por vezes conflitantes, que indicam caminhos para uma humanidade autêntica (TRACY, 1994, p. 107-108).

\subsection{A esperança da interpretação}

Tracy afirma que intérpretes que estão comprometidos existencialmente com alguma identificação religiosa estão envolvidos de tal forma com a reflexão acerca da Realidade Última que são transformados por ela (TRACY, 1994, p. 108). Caberia perguntar se aqueles que interpretam os clássicos religiosos em busca de sua sabedoria, mesmo sem a crença nesta assim denominada Realidade Última também não seriam transformados por esta conversa.

De qualquer modo, ao se tentar falar desta Realidade Última deve se ter em mente que um discurso apropriado deve lidar com a impossibilidade de domínio sobre esta realidade. Tracy nega que apenas crentes possam interpretar os clássicos religiosos, em continuidade com sua perspectiva de que a interpretação dos clássicos religiosos não pode ser nem privatizada nem elitizada. Daí a possibilidade tanto de leituras públicas, quanto de leituras a partir de baixo. Mesmo assim, o autor deixa clara a sua posição de alguém que acredita em Deus e que sua fala se dá a partir desta tomada de posição, bem como acredita que é justamente este local de fala que pode dar esperança e, por conseguinte, nutrir resistência e ação. Mas o autor também acredita que a interpretação dos clássicos religiosos não deva ser restrita a pessoas de fé. Pois a força dos clássicos está justamente em suscitarem respostas várias que podem ser respostas de fé ou ainda distintas formas de iluminação da existência (TRACY, 1994, p. 109-111).

Desse modo, a pluralidade de interpretações se mostra abundante, bem

como a necessidade do reconhecimento das ambiguidades das interpretações das 
religiões e das próprias religiões como estão constituídas. Este quadro evoca uma postura crítica. Por outro lado, há também a esperança da conversa; da relevância da reflexão sobre a vida; para os crentes há a esperança em forma de confiança na Realidade Última; há a esperança da resistência; esperança na esperança; esperança de superação de compreensões anteriores acerca da esperança. Para crentes e não crentes a esperança pode emergir da conversa com os clássicos religiosos, seja por meio da fé, seja por meio da descoberta de elementos que ajudem a pensar a vida (TRACY, 1994, p. 112-113).

Ao concluir sua reflexão, Tracy aponta que a esperança que tentou desenvolver é a seguinte:

[...] que todos aqueles envolvidos na interpretação de nossa situação e todos aqueles conscientes de nossa necessidade por solidariedade possam continuar arriscando a interpretação de todos os clássicos de todas as tradições. Assim, no esforço da interpretação estão a resistência e a esperança (TRACY, 1994, p. 114, tradução própria9).

Nestes termos, o autor afirma que quem se engaja na luta pela esperança o faz em favor de todas as pessoas e age de acordo com o que se pode esperar de um ser humano e, em seus termos, está de acordo com a imagem de um Deus que formou o ser humano para tanto, para a resistência, para a reflexão, para a ação. “O resto é oração, observância, disciplina, conversação e atitudes de solidariedade-naesperança. Ou o resto é silêncio” (TRACY, 1994, p. 114, tradução própria). ${ }^{10}$

Em resumo, a esperança da interpretação está na conversação com os clássicos, na perspectiva de interpretação da situação contemporânea, na possibilidade de encontrar nos clássicos alguma iluminação que auxilie a pensar uma existência humana não centrada em si mesma, mas voltada para a solidariedade.

\footnotetext{
9 “[...] that all those involved in interpreting our situation and all those aware of our need for solidarity may continue to risk interpreting all the classics of all the traditions. And in that effort to interpret lie both resistance and hope".

10 "The rest is prayer, observance, discipline, conversation, and actions of solidarity-in-hope. Or the rest is silence".
} 


\section{Interpretando a religião: contribuições tracyanas ao estudo teológico da religião}

O presente texto se dedicou à compreensão do trabalho teológico de David Tracy em sua investigação sobre a religião com o intuito de perceber caminhos e possibilidades para a continuação dos estudos teológicos da religião no contexto brasileiro. $\mathrm{O}$ autor se dedica ao estudo da religião sempre em diálogo profícuo com importantes pesquisadores do tema em distintas ciências, o que demonstra a relevância do constante diálogo entre os saberes que se ocupam da religião. Com efeito, a contribuição tracyana é aqui sintetizada em cinco pontos:

a) Uma abordagem não totalizante da religião: Uma conceituação rígida e totalizante da religião não é desejável em virtude da complexidade de tal fenômeno. Nota-se que toda expressão da experiência religiosa é sempre apenas relativamente adequada. Com isso, a linguagem do limite se mostra como uma forma pertinente de análise na medida em que aponta para algo comum entre experiências religiosas e que está ligada a tentativa de dar sentido a tais vivências, revelando algo da existência humana que poderá encontrar alguma forma de expressão a ser compartilhada e interpretada. Neste contexto, é importante salientar que cada religião particular é espaço privilegiado para o estudo e compreensão do fenômeno religioso.

b) Pluralidades e ambiguidades: Em virtude do quadro teórico aqui investigado é possível evidenciar o tema do pluralismo como recorrente em Tracy. Cabe indicar que este pluralismo deve ser visto em distintos horizontes, a saber, o pluralismo religioso, o pluralismo de abordagens teóricas, além do reconhecimento dos pluralismos e ambiguidades internas à cada religião particular, bem como das interpretações sobre a religião. Assim, toda abordagem em favor da religião deve reconhecer suas próprias ambiguidades, indicando a impossibilidade de uma teorização ingênua da religião. Reconhecer as ambiguidades também históricas faz parte deste processo de construção do pensamento teológico sobre a religião na atualidade. 
c) A imaginação analógica: A imaginação analógica na conversação é aquela que busca semelhanças-na-diferença e, deste modo, percebe a possibilidade de que se encontrem elementos comuns, bem como que ocorram conflitos de interpretações. Arte e religião são análogas, isto é, semelhantes-na-diferença: Assim como nos estudos de religião, também nos estudos da arte o fenômeno sempre ultrapassa o método. Com isso, os estudos da religião possuem certas particularidades assemelhadas às particularidades dos estudos da arte, ao que as discussões sobre o lugar da teologia na universidade podem e devem ser plasmadas pelas pesquisas epistemológicas das artes e humanidades sensíveis às suas dimensões estéticas.

d) O diálogo com os clássicos: Os clássicos religiosos são aqueles que resistem à dominação e que, sempre de novo, levam seus intérpretes a desvendamentos de sentido. Com isso, a conversação com os clássicos diz respeito a uma predisposição de abertura a ponto de que aquele que entra na conversa coloca em risco suas précompreensões, pois, no diálogo, o protagonismo está com o assunto. Além disso, é também importante ressaltar que a conversação entre as religiões deve evitar reducionismos e valorizar as diferenças. As religiões não são iguais, suas particularidades é que aprofundam a conversa. Isto posto, é possível destacar, com Tracy, que há esperança! A esperança está na conversa com os clássicos, nos desvendamentos de sentido, nas iluminações oriundas da interpretação das tradições religiosas, na vida das pessoas que assumem o risco da interpretação.

e) A dimensão profética das religiões e dos estudos da religião: As religiões não podem ser reduzidas à ética. Por outro lado, a dimensão ético-política das religiões merece destaque. Em especial, a tradição místico-profética como das tradições judaica e cristã aponta para um cuidado preferencial com aqueles e aquelas que mais sofrem. Esta mesma tradição aponta para uma auto criticidade na interpretação da religião. Com efeito, esta disposição crítica às religiões e às interpretações das religiões também pode estar consciente da relevância da análise das religiões vividas, das experiências populares, das teologias do cotidiano. Com 
isso, o estudo das religiões se configura como o estudo das experiências religiosas várias, bem como das expressões teológicas destas vivências.

\section{Conclusão}

O estudo aqui desenvolvido permite apontar para uma teoria sobre a teologia enquanto ciência que se ocupa da religião ${ }^{11}$. Mais precisamente, pensa-se o fazer teológico como interpretação das expressões ligadas aos desvendamentos de sentido causadas por aquilo que Tracy denomina de dimensão religiosa da existência. Como contribuições tracyanas ao estudo teológico da religião, portanto, destacam-se uma abordagem não totalizante da religião; a percepção das pluralidades e ambiguidades que envolvem a investigação da religião e das interpretações da religião; a possível imaginação analógica entre religião e arte; a conversação com os clássicos religiosos de cada expressão particular da religião como fontes que ajudam a pensar a realidade atual, bem como as situações e questões limítrofes da existência humana; a perspectiva de uma dimensão profética das religiões e dos estudos da religião enquanto dinâmica de constante criticidade nas interpretações das tradições teológicas e das situações contemporâneas.

\section{REFERÊNCIAS}

ADAM, Júlio Cézar. Deus e o Diabo na terra do sol. Religião vivida, conflito e intolerância em filmes brasileiros. Estudos de Religião, São Bernardo do Campo, v. 31, p. 77-99, 2017.

ADAM, Júlio Cézar. Teologia em movimento: perspectivas da teologia prática como hermenêutica da religião vivida a partir do cinema brasileiro. Numen, Juiz de Fora, v. 21, p. 114-128, 2018.

BECKE, Andreas. Hinduismus. Zur Einführung. Hamburg: Junius, 1996.

HICK, John. Teologia cristã e pluralismo religioso. O arco-íris das religiões. São Paulo: Attar; Juiz de Fora: PPCIR, 2005.

\footnotetext{
${ }^{11}$ Sobre a relação entre ciência da religião com recurso ao conceito de uma teologia pública, inclusive com referência a David Tracy, ver Teixeira (2013, p. 175-183).
} 
HICK, John. Uma interpretação da religião: respostas humanas ao transcendente. Petrópolis: Vozes, 2018.

LUTERO, Martinho. Da vontade cativa [1525]. In: LUTERO, Martinho. Obras selecionadas. São Leopoldo: Sinodal; Porto Alegre: Concórdia, 1993. v. 4. p. 11-216.

OTTO, Rudolf. O Sagrado. Os aspectos irracionais na noção do divino e sua relação com o racional. São Leopoldo: Sinodal; Petrópolis: Vozes, 2007.

PASSOS, João Décio; USARSKI, Frank (org.). Compêndio de ciência da religião. São Paulo: Paulinas: Paulus, 2013.

PICH, Roberto Hofmeister. Religião como forma de conhecimento. In: PASSOS, João Décio; USARSKI, Frank (org.). Compêndio de ciência da religião. São Paulo: Paulinas: Paulus, 2013. p. 143-160.

SINNER, Rudolf von. Teologia pública num estado laico - ensaios e análises.. São Leopoldo: Sinodal; EST, 2018. (Teologia pública v. 7).

SOARES, Afonso Maria Ligorio; PASSOS, João Décio (org.). Teologia pública. Reflexões sobre uma área de conhecimento e sua cidadania acadêmica. São Paulo: Paulinas, 2011.

TEIXEIRA, Faustino. Campo religioso em transformação. Comunicações do ISER, Rio de Janeiro, n.69, p. 34-45, 2014.

TEIXEIRA, Faustino. Ciência da Religião e Teologia. In: PASSOS, João Décio; USARSKI, Frank (org.). Compêndio de ciência da religião. São Paulo: Paulinas: Paulus, 2013. p. 175-183.

TRACY, David. A imaginação analógica: a teologia cristã e a cultura do pluralismo. São Leopoldo: Editora UNISINOS, 2006.

TRACY, David. Blessed rage for order: the new pluralism in theology. New York: The Seabury Press, 1975.

TRACY, David. Martin Luther's Deus Theologicus. In: MALYSZ, Piotr J.; NELSON, Derek R. (org.). Luther refracted: The reformer's ecumenical legacy. Minneapolis: Fortress, 2015. p. 105-140.

TRACY, David. Plurality and ambiguity: hermeneutics, religion, hope. Chicago: The University of Chicago Press, 1994.

TRACY, David; ELIADE, Mircea. Editorial. O que é religião? Uma questão para a teologia católica. Concilium, n. 156, p. 3-6 [707-710], 1980.

VÄHÄKANGAS, Mika. Interreligious and Interchurch Debates. In: PIERCE, Andrew; SCHUEGRAF, Oliver (org.). Den Blick weiten: Wenn Ökumene den Religionen begegnet. Tagungsbericht der 17. Wissenschaftlichen Konsultation der Societas Oecumenica. Leipzig: Evangelische Verlagsanstalt, 2014. p. 51-67. 
VÄHÄKANGAS, Mika. Mission studies, syncretism and the limits of Christianity during the time of the heretical imperative. Swedish Missiological Studies, v. 98, n. 1, p. 7-22, 2010.

WIRTH, Lauri Emílio. Religião e epistemologias pós-coloniais. In: PASSOS, João Décio; USARSKI, Frank (org.). Compêndio de ciência da religião. São Paulo: Paulinas: Paulus, 2013. p. 129-142.

ZEFERINO, J. Karl Barth e teologia pública: contribuições ao discurso teológico público na relação entre clássicos teológicos e res publica no horizonte da teologia da cidadania. Tese (Doutorado). Programa de Pós-Graduação em Teologia - Pontifícia Universidade Católica do Paraná, Curitiba, 2018. 